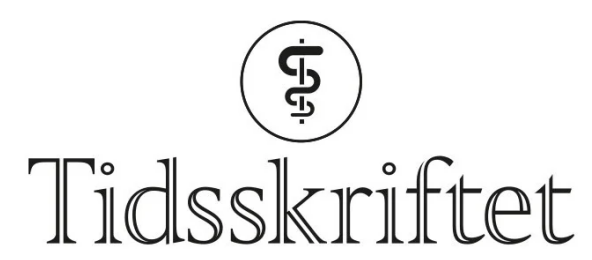

DEN NORSKE LEGEFORENING

\title{
Klassiker i ny utgave
}

\author{
ANMELDELSER
}

ODDVAR SANDVIK

Kirurgisk avdeling

Stavanger universitetssjukehus

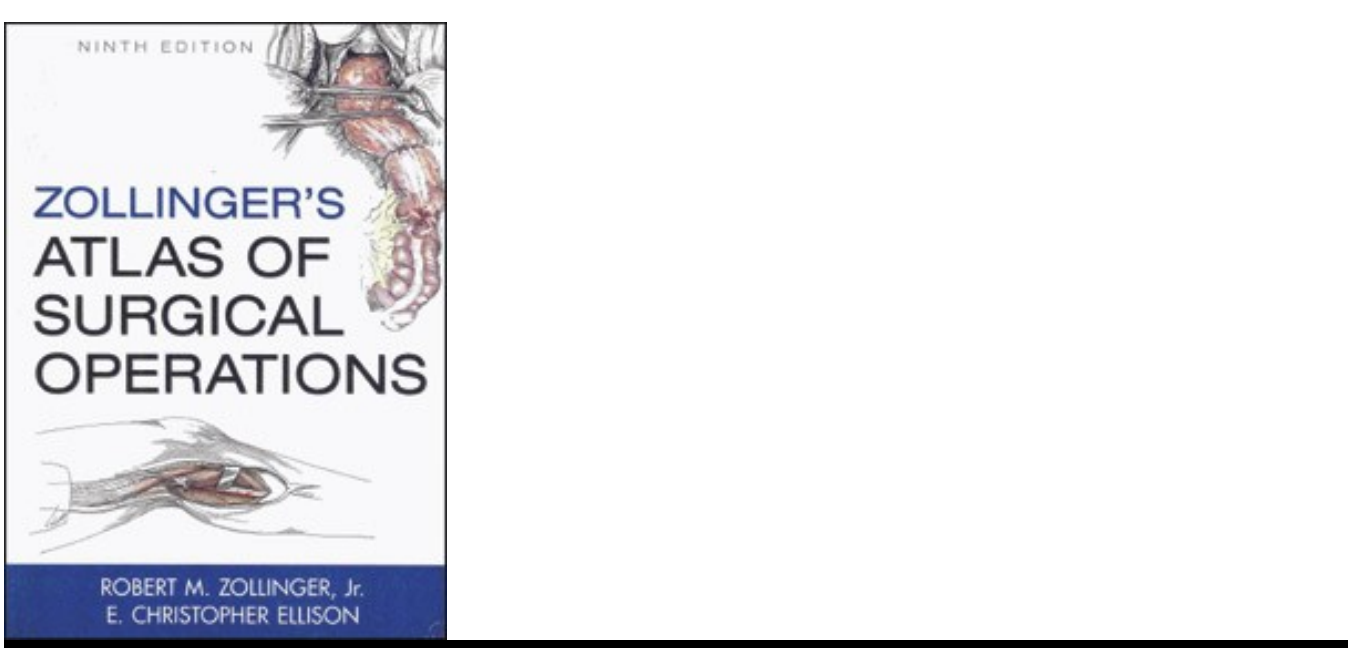

Zollinger Jr., Robert M.

Ellison, E. Christopher

Zollinger's atlas of surgical operations

9. utg. 506 s, tab, ill. New York, NY: McGraw-Hill, 2010. Pris USD 249

ISBN: 978-0-07-160226-6

Førsteutgaven av dette operasjonsatlaset kom i 1939, så forlaget har vel en viss dekning for å kalle det en klassiker når det nå er revidert for åttende gang. Verkets forskjellige utgaver gjenspeiler utviklingen av den moderne kirurgien. Forfatterne (ja, det er sønnene til dem som beskrev syndromet), trekker selv frem de to mest epokegjørende forandringene, nemlig utviklingen av stiftemaskiner i 1970-årene og innføring av minimalinvasive metoder fra begynnelsen av 1990-årene. Målet med atlaset, den gang som i dag, er å dokumentere etablerte og trygge kirurgiske teknikker som er i vanlig bruk blant generelle kirurger. 
I de innledende korte kapitlene tar forfatterne for seg kirurgisk teknikk, anestesi, preoperative forberedelser, postoperativ oppfølgning og dagkirurgi. I kapitlet om kirurgisk anatomi fokuserer de på viscerale kar.

Hovedtyngden av de rundt 230 prosedyrene omfatter det vi sorterer under generell og gastroenterologisk kirurgi, men det er også plass til sentrale karkirurgiske, endokrinkirurgiske og gynekologiske inngrep. Vi får beskrevet veien inn til thoraxhulen (posterolateral thorakotomi), men ikke hva vi eventuelt skal foreta oss der. Urologiske emner er dessverre helt utelatt. Repertoaret er utvidet med en del laparoskopiske prosedyrer som høyre- og venstresidig kolektomi, distal miltbevarende pancreasreseksjon, gastrisk bypass, gastrisk banding og adrenalektomi.

Forfatterne beskriver prosedyrene strukturert. På venstre side er det en lettlest tekst med punktvis gjennomgang av indikasjoner, preoperative forberedelser, anestesi, leiring, incisjon og eksposisjon, prosedyrens detaljer, lukning og postoperativ oppfølging. På motstående side finner vi illustrerende strektegninger som stort sett er gode og belyser viktige steg i prosedyrene. De er for første gang fargelagt, og det hever utvilsomt kvaliteten. Til sammen gir tekst og tegninger en ganske detaljert innføring i de ulike operative teknikkene. I mange sammenhenger omtales alternative måter å løse kirurgiske utfordringer på, noe som er nyttig. Hvis forfatterne har lyktes med sin målsetting med atlaset, kan vi konstatere at amerikanske kirurger er ganske konservative. Tykktarm tømmes før reseksjon, tarmanastomoser sys i to lag, buksnitt lukkes i alle lag - for å nevne noen eksempler. Imidlertid har moderne prinsipper for perioperativ behandling begynt å diffundere inn i boken.

Med strategiske mål $36 \times 26 \times 3 \mathrm{~cm}$ og 2,5 kg er atlaset forbeholdt de aller største frakkelommene. Godt da at det ifølge forordet skal finnes en nettutgave (via www.accesssurgery.com), hvor det er mulig å laste atlaset ned til håndholdte Internett-lesere. Jeg fant riktignok kun forrige utgave, og siden tilgangen omfatter flere bøker fra forlaget, er prisen ganske høy. Apropos pris: amazon.de tar i dag 1369 kroner for bok og transport, amazon.com 1566 kroner og amazon.co.uk 1848 kroner - det kan svare seg å sammenlikne.

Zollinger's atlas of surgical operations står nok i de fleste sykehusbibliotek i en eldre utgave, den bør nå oppdateres!

Publisert: 4. mars 2011. Tidsskr Nor Legeforen. DOI: 10.4045/tidsskr.10.1408

(C) Tidsskrift for Den norske legeforening 2023. Lastet ned fra tidsskriftet.no 26. april 2023. 